\title{
Gregos e baianos: o drama $O$ pagador de promessas e sua relação com a tragédia grega clássica
}

\author{
Júlio Cesar Lobo ${ }^{1}$
}

\begin{abstract}
Resumo: O objetivo principal desse ensaio é analisar a peça $O$ pagador de promessas, de Dias Gomes, comparando a sua estrutura dramática com elementos centrais da tragédia grega clássica. Nossas premissas são: há uma atualização de princípios da tragédia ática, há a reafirmação do prestígio do culto católico, e há a afirmação do candomblé através da evocação de Iansã ao final dessa narrativa.

Palavras-chave: O pagador de promessas; Cultos afro-brasileiros; Tragédia grega clássica; Mitologia grecolatina ; Dias Gomes (1922-1999).
\end{abstract}

\begin{abstract}
The main objective of this essay is to analyze the play The word given, by Dias Gomes, comparing its dramatic structure with central elements of classical Greek tragedy. Our assumptions are: there is an update of principles of Attic tragedy, there is a reaffirmation of the prestige of Catholic worship, and there is the statement of Candomblé through the evocation of Iansã the end of this narrative.
\end{abstract}

Keywords: The word given; Afrobrazilian cults; Classic Greek tragedy; Greco-Latin mythology; Dias Gomes (19221999).

Martin Bernal, em Black Athena, diz que a concepção que a maioria de nós tem hoje sobre a Grécia clássica não corresponde ao que os autores gregos daquele período contam. Desde o começo do século XIX, europeus e americanos cresceram ouvindo uma versão idealizada de harmonia e graça ática, imaginando Atenas como um lugar onde filósofos ocidentais iluminados, como Platão e Aristóteles, transmitiram sua sabedoria, onde a democracia nasceu e onde, de todas as maneiras possíveis, dominava um modo de vida ocidental completamente diferente do asiático ou africano. [...] Bernal vai além e demonstra, lançando mão de muitas fontes, que a Grécia era originalmente uma colônia da África, mais particularmente do Egito, e que mercadores, marinheiros e professores fenícios e judeus contribuíram muito para o que conhecemos hoje como cultura grega clássica, que ele considera um amálgama de influências africanas, semíticas e, num momento posterior, setentrionais.

Edward Said, Reflexões sobre o exílio, 2003.

\section{Zé-do-burro:}

- Nesse negócio de milagres, é preciso ser honesto. Se a gente embrulha o santo, perde o crédito. De outra vez, o santo olha, consulta lá os seus assentamentos, e diz: - Ah, você é o Zé-do-burro, aquele que já me passou a perna! E, agora, vem me fazer nova promessa. Pois vá fazer promessa pro diabo que o carregue, seu caloteiro de uma figa! E tem mais: santo é como gringo, passou calote num, todos os outros ficam sabendo.

(Dias Gomes, O pagador de promessas, Ato I, $1^{\circ}$ quadro)

1 Júlio César Lobo é licenciado em Letras pela UFBA (1978) e doutor em Ciências da Comunicação pela USP (2002). É autor de Cinema e sociedade no Brasil (EDUFBA, no prelo) e coautor de Glauber, a conquista de um sonho (Belo Horizonte, Dimensão, 1995). Entre os anos de 1967 e 1968, foi ator e diretor teatral em Salvador. 


\section{Introdução}

O objetivo principal desse ensaio é analisar a peça $O$ pagador de promessas, do escritor baiano Dias Gomes (1922-1999), que trata, muito resumidamente, dos percalços que enfrenta um pequeno produtor rural da Bahia ao tentar entrar com uma imensa cruz na igreja de Santa Bárbara em Salvador. O principal impasse enfrentado por ele com uma autoridade católica diz respeito ao fato de ele ter feito uma promessa à Santa Bárbara - pela recuperação de seu burro, vítima de raios - diante de uma imagem dessa santa num terreiro de candomblé. Acreditamos que esse texto, escrito em 1959 e estreado nos palcos em 1960, dramatiza com acuidade algumas dinâmicas do sincretismo religioso - para não dizer de aspectos culturais da diáspora africana - no Brasil.

A nossa abordagem da peça $O$ pagador de promessas, em linhas gerais, busca compará-la com a estrutura da tragédia grega clássica ao passo em que associa, em termos bem gerais, elementos do panteão afro-brasileiro com o panteão do politeísmo da Grécia clássica, a partir das premissas teóricas de M. Bernal e E. Said, citados em epígrafe. Um outro movimento de análise se constrói simultaneamente visando criar as condições para as nossas seguintes apostas: há uma atualização de princípios da tragédia ática, há a reafirmação do prestígio do culto católico, há a afirmação do candomblé, através da evocação de Iansã ao final da peça. No aspecto, digamos estrutural, buscaremos apontar convergências a partir da observação, na peça brasileira, da vigência dos seguintes itens: princípio das três unidades; caracterização do protagonista, ora como determinado e arrogante (através do "solene e desmedido" excesso de suas atitudes), ora como humilde (reconhecendo sua desorientação, seu erro, sua culpa, aceitando o seu castigo e sofrendo conscientemente); presença da peripécia, e o enredamento do protagonista numa contradição inconciliável.

Ainda com relação à estrutura da tragédia clássica grega e a estrutura de O Pagador de Promessas, buscaremos também apontar divergências na caracterização do protagonista, na divisão da peça e, principalmente, com relação à carpintaria teatral do seu desfecho com a inobservância, em nosso entendimento, dos fatores ideais, segundo Aristóteles, para a criação dos efeitos principais da tragédia: o temor de que o que aconteceu com o protagonista aconteça conosco, leitores ou espectadores, e a compaixão pelo destino dele, um semelhante nosso. Ao passo em que buscamos um trabalho em termos de uma análise estética, trabalhando nos limites dos instrumentais disponíveis, recompor o que seria uma trilha de construção da peça de Dias Gomes, achamos pertinente efetuar uma contextualização das questões de fundo da peça - sincretismo religioso, 
intolerância, reforma agrária e a consolidação de uma indústria cultural, tendo como exemplo um jornal diário e seus vínculos com o mercado. Nesse movimento, através de uma análise de personagens, trazemos ao primeiro plano muitas de suas personagens tidas como secundárias, a exemplo do poeta de cordel Dedé Cospe-Rima, a ekédi Minha Tia e o Repórter, entre outras.

\section{A motivação}

Em termos formais, a peça O pagador de promessas, de Dias Gomes, obedece aos seguintes requisitos formulados por Aristóteles (1998, p.24;45) em sua Poética, a saber:

a) a unidade de tempo: "A tragédia, com efeito, empenha-se, o quanto possível, em não passar duma revolução do sol ou superá-la de pouco". O drama em pauta começa às quatro e meia da manhã, quando o protagonista se desloca de sua pequena propriedade rural em direção à cidade, e se encerra no entardecer do dia de Santa Bárbara, 4 de dezembro;

b) a unidade de ação: "Deve-se compor as fábulas, tal como nas tragédias, em forma dramática, em torno de uma só ação inteira e completa com início, meio e fím, para que, como um vivente uno e inteiro, produza o prazer peculiar seu". Toda a trama dessa peça gira em torno de uma só ação: a determinação de Zé-do-burro em entrar na igreja de Santa Bárbara, em Salvador, para lá depositar uma imensa cruz de madeira, que ele viera carregando nas costas de uma distância de 42 quilômetros; e

c) a unidade de espaço, a rigor, a peça transcorre em um só lugar, o Pelourinho com exceção de uma sequência no interior de um jornal.

Outros aspectos da teoria aristotélica sobre a tragédia estão presentes ainda no drama em foco, a saber:

a) o "solene e desmedido excesso", item caro à tragédia ática, é um dos elementos mais acentuados nesse drama fílmico, tanto para o prosaico guarda-de-trânsito - “...mas o senhor bem 
que podia ter arranjado uma promessinha menos complicada" - quanto para o Padre, obstáculo maior para o cumprimento de sua promessa: "Não lhe parece um tanto exagerada a promessa? E um tanto pretensiosa, também?";

b) o reconhecimento pelo protagonista de sua situação de isolamento como consequência do erro cometido (mudança do desconhecimento ao conhecimento, ou à amizade, ou ao ódio, das pessoas marcadas para a ventura ou desdita): "Ninguém me entende. Aquela mulher me chamou de herege, o Padre fechou a porta da igreja, como se eu fosse Satanás em pessoa. Eu, Zé-do-burro, devoto de Santa Bárbara". Zé balança a cabeça, sentindo-se perdido e abandonado: "Santa Bárbara me abandonou! Por quê? Eu não sei... não sei!";

1. a desorientação como consequência do que foi afirmado acima: "Há duas horas tento compreender... mas estou tonto, tonto como se tivesse levado um coice no meio da testa. Já não entendo nada... parece que me viraram pelo avesso, e estou vendo as coisas ao contrário do que elas são"; e

d) o reconhecimento da culpa e a aceitação do castigo correspondente na fé dele: "Bem Maria de Iansã disse: a promessa tinha que ser bem grande...Com certeza, Santa Bárbara achou que não era bastante o que eu prometi e está cobrando o restante. Ou está me castigando por eu ter prometido tão pouco".

Quase todas as pessoas com que Zé se depara colocam para ele a alternativa de desistir da empreitada. E em cada uma dessas oportunidades, ele manifesta a sua determinação em perseguir em seu intento. Além de mostrarem esse traço firme da personalidade do protagonista, essas cenas servem também para mostrar a incidência na oportunidade de escolha e na persistência do erro. Esses momentos se constituem também em provas para o protagonista, provas essas que lhe são lançadas em várias oportunidades pelas seguintes pessoas por ordem de entrada em cena: Rosa (por sinal, durante todo o tempo), Padre, a ekédi Minha Tia, Monsenhor, Mestre Coca (o líder dos capoeiristas), o poeta popular Dedé Cospe-rima e Delegado, a saber:

Rosa: Você já pagou a sua promessa, já trouxe uma cruz de madeira da roça até à igreja de Santa Bárbara. Está aí a igreja de Santa Bárbara, está aí a cruz. Pronto. Agora, vamos embora.

Zé: Mas aqui não é a igreja de Santa Bárbara. A igreja é da porta para dentro. 
(...) Eu prometi levar a cruz até dentro da igreja, tenho que levar. (Ato I, $1^{\circ}$ quadro)

-Zé, vamos embora daqui.

-Agora?

-Sim, agora mesmo.

-Não posso. Você sabe que eu não posso voltar antes de chegar ao fim da promessa. Não ia ter sossego o resto da vida. (Ato II, $1^{\circ}$ quadro)

Zé: Eu nunca fui muito de frequentar terreiro de candomblé, mas o pobre Nicolau estava morrendo. Não custava tentar. Se não fizesse bem, mal não fazia. E eu fui. Contei pra mãe-de-santo o meu caso. Ela disse que era mesmo com Iansã, dona dos raios e das trovoadas. Iansã tinha ferido Nicolau... pra ela eu devia fazer uma obrigação, quer dizer: uma promessa, mas tinha que ser uma promessa bem grande, porque Iansã, que tinha ferido Nicolau com um raio, não ia voltar atrás por qualquer bobagem. E eu me lembrei então que Iansã é Santa Bárbara e prometi que, se Nicolau ficasse bom, eu carregava uma cruz de madeira de minha roça até a igreja dela, no dia de sua festa, uma cruz tão pesada como a de Cristo.

Padre: Um ritual pagão, que começou num terreiro de candomblé, não pode terminar na nave de uma igreja!

Zé: Mas Padre, a igreja...

- A igreja é a casa de Deus. Candomblé é o culto do diabo!

-Padre, eu não andei sete léguas para voltar daqui. O senhor não pode impedir a minha entrada. A igreja não é sua, é de Deus! (Ato I, $\mathbf{2}^{\mathbf{0}}$ quadro).

Minha Tia: Meu filho, eu sou ekédi no candomblé da Menininha. Mais logo, o terreiro está em festa. Você fez obrigação pra Iansã, Iansã está lá prá receber!

- Como?

- Eu levo você lá! Você leva a cruz, e a Santa recebe! Você fica em paz com ela! - Iansã...

- Foi ela quem lhe atendeu!

- Mas a igreja...

- Mande pro inferno! Leva a sua cruz no terreiro! Eu vou com você

- Não, não foi num terreiro que eu disse que ia levar a cruz, foi numa igreja. Numa igreja de Santa Bárbara.

- Santa Bárbara é Iansã. E Iansã está lá! Vai baixar nos seus cavalos! Vamos!

- Não, não é a mesma coisa. Não é a mesma coisa.

Monsenhor: Vamos lhe dar uma oportunidade. Se é católico, renegue todos os atos que praticou por inspiração do Diabo e volte ao seio da Santa Madre Igreja.

Zé-do-burro: Como, Padre?

- Abjure a promessa que fez, reconheça que foi feita ao Demônio, atire fora essa cruz e venha, sozinho, pedir perdão a Deus.

- O senhor acha mesmo que eu devia fazer isso?

- É a única maneira de salvar-se. A igreja católica concede a nós, sacerdotes, o direito de trocar uma promessa por outra.

- ...talvez fosse melhor.

- Mas Rosa... se eu faço isso, estou faltando à minha promessa... seja Iansã, seja Santa Bárbara... estou faltando... 
- Com a autoridade de que estou investido, eu o liberto dessa promessa, já disse. Venha fazer outra.

$-(\ldots)$

- Decida: renega ou não renega?

$-(\ldots)$

- Não! Não posso fazer isso! Não posso arriscar a vida do meu burro!

$-(\ldots)$

- Nada mais posso fazer então.

Capoeirista (Mestre Coca):

Coca (A Zé-do-burro): Meu camarada, trate de ir embora! Estão lhe arrumando uma patota!

Zé: O quê?

Coca: Chegou um carro da Polícia! Eles estão com o Padre, na sacristia.

Minha Tia: Vieram por causa dele?

Coca: Então!

Zé: Mas eu não roubei, não matei ninguém!

Dedé: Quer um conselho? Experiência própria: com a Polícia, é melhor fugir do que discutir.

Coca: Ande depressa que nós aguentamos eles aqui até você ganhar o mundo!

Zé: Não, eu não vou fugir como qualquer criminoso, se estou com a minha consciência tranquila (Ato III).

Delegado: Vamos, acompanhe-me.

- Acompanhar o senhor... pra quê?

- Mais tarde, você verá. Sou delegado deste distrito. Obedeça.

- Não posso. Não posso sair daqui.

A fala em que fica mais claro que o erro de Zé tende a encaminhá-lo para um desenlace infeliz vem do Padre, seu maior antagonista: "Este homem teve todas as oportunidades para arrepender-se. Deus é testemunha de que fiz todo o possível para salvá-lo. Mas ele não quer ser salvo". Finalmente ainda a propósito do tópico culpa e castigo, o protagonista é posto em prova, em seu entendimento, até pela Santa:

- A promessa tinha que ser bem grande... Com certeza Santa Bárbara achou que não era o bastante o que eu prometi e está cobrando o restante [...] ou pode ser que esteja me fazendo passar por tudo isto prá me experimentar. Prá ver se eu desisto da promessa. Santa Bárbara está me tentando... e, ainda há pouco, quase eu caio.

Buscando uma abordagem mais contemporânea rumo a uma teoria da tragédia, Lesky (2003, 
p.32-34) sistematiza o que seriam os requisitos mínimos para se falar em efeito trágico, a saber: a "dignidade da queda", o herói deve "ter consciência de seu erro e sofrer conscientemente" e a possibilidade de "relação da trama com o nosso próprio mundo". Com relação ao primeiro dos itens citados, ele o associa a uma condição, a "considerável altura da queda", ou seja: "O que temos de sentir como trágico deve significar a queda de um mundo ilusório de segurança e felicidade para o abismo da desgraça inelutável". Na peça em discussão, os dados de segurança e felicidade de Zédo-burro, associados à vida no campo, não são mostrados em cena, mas, sim, relembrados por ele e por Rosa. Com relação ao segundo aspecto - o herói "deve ter consciência de seu erro e sofrer conscientemente" -, Lesky acrescenta: "Onde uma vítima sem vontade é conduzida surda e muda ao matadouro, não há impacto trágico. Esse "sofrer conscientemente" fica mais nítido do que nunca nessa sequência de diálogos entre Zé e Secreta (um policial da Inteligência):

Secreta: O senhor sabe que suas ideias são muito perigosas?

Zé: Perigosas?

- O senhor não devia dizer isso no jornal. E, muito menos, aqui, em praça pública. Porque isso pode lhe dar muita aporrinhação.

- Mais do que já tive?

- Por muito menos, tenho visto muita gente ir parar no xadrez.

- Xadrez?

- Xadrez?

- Estou avisando como amigo.

-Amigo. Já vi que estou cercado de amigos. É amigo por todo lado... Cada qual querendo ajudar mais do que o outro.

- O senhor é um revoltado.

-Não era, não. Mas estou ficando.

- É por isso que está aqui desde esta madrugada?

- É (Inflamando-se). E daqui não saio enquanto não fizer com que todo mundo me

Entenda! Todo mundo!

- Como pretende fazer isso?

- Como... sei lá... mas tem de haver um jeito... tem de haver um jeito.... (Desesperado) A vontade que eu tenho é de jogar uma bomba. [...] Padre! Padre! Padre, eu andei sete léguas pra vir até aqui! Deus é testemunha! Ainda não comi hoje... e não vou comer até que abra a porta! Um dia... dois... um mês... vou morrer de fome na porta de sua igreja, padre! (Ato II, $2^{\circ}$ quadro).

Lesky (2003, p.31;35;37) nos fornece ainda uma síntese sobre a questão do trágico para além das formas da tragédia ática, síntese que tornaria talvez pertinente a aproximação que se busca aqui da peça $O$ pagador de promessas com o citado gênero clássico. Inspirado por uma observação de Goethe - "Todo o trágico se baseia numa contradição inconciliável. Tão logo aparece ou se torna 
possível uma acomodação, desaparece o trágico”. Esse autor procura atualizar a discussão argumentando: "A absoluta falta de solução para o conflito trágico foi convertida precisamente por algumas teorias modernas em ponto central e em requisito fundamental para a realização da autêntica tragédia”. Ele toma o conceito goetheano como um ponto de partida para essas considerações: “A contradição trágica pode situar-se no mundo dos deuses, e seus polos opostos podem chamar-se Deus e homem ou pode tratar-se de adversários, que se levantem um contra o outro no próprio peito do homem" (LESKY, 2003, p. 37. O fato é que a linha de raciocínio desse teórico teatral tende a defender o trágico como "algo incondicionalmente irremediável". É claro que ele faz questão de destacar que há tragédias com finais conciliadores e até algumas delas com finais felizes.

Mas o que nos importa aqui, nesse tópico sobre o trágico além da tragédia, é a reverberação da afirmação goethiana, que encontra, nessa peça, um exemplo cristalino. Não há possibilidade de solução para o problema criado por Zé-do-burro ao querer entrar na igreja de Santa Bárbara para pagar a sua promessa. Como sugere Goethe, e Lesky retoma, o conflito trágico aqui se estabelece na constatação de que ambos os lados têm "razão". Na peça em discussão, Zé tem "razão" em querer entrar, pois a sua promessa tem que ser paga numa igreja de Santa Bárbara. O Padre também tem "razão", pois, em seu entendimento, a promessa feita em um terreiro de candomblé não deve ser paga em uma igreja. Na mesma linha do pensamento goeteano, Lesky (2003, p.49) chama-nos a atenção para a contribuição à essa discussão da ideia schopenhaueriana do trágico das circunstâncias: “(Ele) se produz quando entram em conflito dois ou mais contrários igualmente válidos".

A contradição em Zé-do-burro: se ele acha que Iansã e Santa Bárbara são a mesma divindade, porque ele não paga a promessa em um terreiro de candomblé? No entanto, se ele assim pensasse, não teríamos um herói "trágico". Não estamos aqui, com isso, defendendo as personagens, nem o catolicismo e nem os candomblés da Bahia, estamos apenas pontuando as "certezas" dos discursos do herói e do vilão.

A certeza de Zé com relação à sua "razão" vai crescendo ao longo da narrativa, e não se tem, em nenhum momento, nenhum sinal de que ele vai fazer um recuo na sua postura: seja ir a um candomblé, como sugerido por Minha Tia, seja entrar na citada igreja sem a cruz. É essa determinação que faz com que tenhamos, na postura de Zé, uma característica da maioria dos heróis trágicos, e não a simples revelação de uma teimosia ou a manifestação de ranzinzices de um 
"cabeça-dura".

\section{Tragédia e cristianismo: incompatibilidades}

O curto e duro diálogo entre o Padre e Zé-do-burro citado acima aponta-nos também para uma das restrições que se faz a uma atualização da tragédia aos nossos dias e com algumas repercussões em nossa proposta analítica: o trágico e o mundo cristão não são compatíveis. Lesky (2003, p.40-41) expõe inicialmente dois argumentos em sua defesa ("o trágico é o estigma do autêntico paganismo, ao passo que o cristão o superou" e "a Redenção não invalida nem as leis da natureza nem as formas contingentes da história" até chegar à sua síntese: "A possibilidade da situação trágica dentro do mundo cristão se dá como em qualquer outro mundo [...] Aquilo que é sofrido até a destruição física pode encontrar, num plano transcendente, seu sentido e, com ele, sua solução".

Já Peter Szondi (2004, p.99) analisando esse impasse, observa que a "tragicidade do destino", marca da Antiguidade clássica, cristianizada, torna-se uma "tragicidade da individualidade e da consciência. Este autor assim se posiciona: “O herói grego cumpre à sua revelia o ato terrível ao tentar evitá-lo; o herói do drama católico torna-se, diante da salvação, vítima de sua tentativa de usar o saber e o pensamento para substituir a realidade ameaçadora por uma outra que ele mesmo cria".

No parágrafo mais acima, temos três conceitos utilizados por Lesky (2003, p.26;38), os quais entendemos necessitaram de uma melhor clarificação. A "visão cerradamente trágica" é uma construção apropriada de Kierkegaard: "O nosso mundo está separado de Deus por um abismo intransponível". Na "situação trágica", há as forças contrárias, que se levantam para lutar umas contra as outras, há o homem, que não conhece a saída do conflito e vê sua existência abandonada à destruição. E "conflito trágico cerrado/fechado" remete a Goethe. Associando o espírito grego clássico à tragédia ática, Lesky se refere à "prestação de contas", ato que justificaria, nas grandes personagens desse gênero, os longos discursos em que elas discorrem sobre os motivos de suas ações, as dificuldades oriundas de suas decisões

e os poderes que elas enfrentam por causa disso.

Dentro do espírito que nos move nesse texto, vamos buscar nessas afirmações acima mais 
alguns pontos (mesmo que tênues) de aproximação da tragédia ática com O pagador de promessas. Em nosso entendimento, esse "sofrer tudo conscientemente" pode ser flagrado mais intensivamente, de acordo com dois dos itens acima discriminados, nos trechos que se seguem, arrolados a partir de itens, a saber: as dificuldades enfrentadas pelo protagonista devido às suas decisões (tidas como fruto de escolhas erradas e os poderes que o protagonista enfrenta no intuito de querer realizar seu intento principal:

O filósofo Gerd Bornheim (1975, p.81) também se dedica a questão tragédia versus cristianismo, partindo da constatação histórica de que a tragédia, com seus princípios e traços formais, somente teria florescido em dois momentos em que houve um "processo de secularização ou laicização da vida humana" - o primeiro na crise do mundo grego homérico (a Grécia do século V) -, e o segundo momento seria durante a crise da religiosidade medieval (a Europa dos tempos modernos). A partir desse horizonte, ele centra a sua argumentação em torno da perspectiva do subjetivismo: "Tragédia, em um sentido forte e pleno, é a grega. A debilidade da tragédia moderna deriva precipuamente do excesso de importância que se empresta à subjetividade, sobretudo quando considerada em seu aspecto moral. A partir da premissa, sintetizada acima, afirma Bornheim (1975, p.83):

É evidente que cristianismo e subjetivismo não se confundem. Acontece porém que, nos tempos modernos, o cristianismo, ao contrário do que acontecera na Idade Média, passa a pactuar mais intensamente com o subjetivismo; o homem cristão, a partir da decadência medieval, se fixa, com exclusividade crescente, na vida interior, na 'imitação de Cristo` compreendida como tarefa subjetiva. É esta preeminência progressiva da vida interior que desvigora o trágico e a extensão objetiva da ação trágica. Na medida em que o subjetivismo dos tempos modernos se torna mais forte, menos exequível a tragédia. Por isso, mais do que dizer que o cristianismo é incompatível com a tragédia, deve-se colocar a raiz da debilidade na intensificação através da história do processo subjetivador do cristianismo.

Mais adiante, no mesmo ensaio, Bornheim (1975, p.87) busca tornar mais concisa a sua argumentação ainda a propósito do propósito subjetivador do cristianismo e a sua relação com o trágico, chamando a atenção para o fato de que o processo de subjetivação em pauta - "a subjetivação do trágico na transformação do sentido da culpa e de suas consequências" - pode ser explicado através do relevo que adquire na cultura moderna a reflexão. "Quanto mais reflexiva se 
tornar a subjetividade, mais o indivíduo se dobra sobre si próprio, enfraquecendo desta forma a experiência trágica".

A despeito dos argumentos expostos acima, Borheim (1975, p.91-92) chega a uma ordem de conclusões, que seguimos, com intuito diverso, é claro, no intuito de demonstrar a propriedade da aproximação da peça brasileira $O$ pagador de promessas de elementos da tragédia grega clássica. Resumidamente, as conclusões desse falecido filósofo brasileiro seriam essas: a) a tragédia, em seu "estado puro" não mais se verifica; b) por outro lado, isso não quer dizer que a "experiência trágica" esteja restrita apenas à Grécia clássica; e c) toda cogitação do trágico, nostálgica ou não, inspira-se no próprio fenômeno trágico.

Com relação à possibilidade de relação com o nosso próprio mundo, o caso deve interessarnos, afetar-nos, comover-nos. Na peça em foco, há vários tópicos contemporâneos à escritura e primeira encenação dessa peça no ano de 1959 em São Paulo, a saber: a) as discussões em torno da necessidade de uma reforma agrária no País; b) o sincretismo religioso e c) a intolerância da igreja católica com relação ao sincretismo. Com relação ao primeiro item arrolado acima, é bom se dizer que as reivindicações em torno da racionalização da propriedade de terras no Brasil se acentuam a partir dos anos 1950. E vão contar desde o início com a participação da igreja católica brasileira em intensidades variadas.

\section{Igreja católica e sincretismo afro-brasileiro}

O outro item do roteiro relativo ao tópico "possibilidade de relação com o nosso próprio mundo" é o desafio que o sincretismo religioso põe para a igreja católica, desafio este que se cristaliza na fala seguinte do Padre: "Esta confusão vem do tempo da escravidão. Os escravos africanos burlavam assim os senhores brancos. Fingiam cultuar santos católicos, quando, na verdade estavam adorando seus próprios deuses. Não só Santa Bárbara, muitos santos foram vítimas dessa farsa".

O fato é que é complexa a discussão sobre o sincretismo religioso no Brasil ou em qualquer outro lugar hoje, ou nos tempos mais remotos, levando-se em consideração a sua diversidade. Assim, para o antropólogo francês Roger Bastide (1983, p.169-170;172), com relação à citada diversidade, tem-se os seguintes sincretismos: a) sincretismo regional: “O sincretismo variará numa 
mesma região de terreiro para terreiro"; b) sincretismo étnico: "Cada orixá é múltiplo. Essa multiplicidade do orixá encontra-se ligada, primeiro, à multiplicidade das nações e mesmo, provavelmente, na origem, à multiplicidade das tribos"; c) sincretismo de tradição; d) sincretismo de imitação; e e) sincretismo mágico.

Roger Bastide denuncia o fato de ser difícil (a pesquisa dele foi feita em 1956) distinguir o sincretismo de tradição daquele de imitação, pois teria que se localizar a data precisa de fundação dos terreiros, sua "genealogia" para identificar os "charlatanismos". Ao buscar definir o sincretismo mágico, Bastide (1983, p.188;190) leva em consideração ainda a lei do pensamento mágico e a lei da acumulação. Ele usa como exemplo da permanência da lei do pensamento mágico a sobrevivência de aspectos da magia muçulmana dos malês em Salvador (isto em 1956), a partir de uma argumentação original de Arthur Ramos, em A acumulação negra no Brasil, de que o sincretismo não toma emprestado apenas elementos do catolicismo brasileiro. A argumentação dele se constrói assim: "Se a lei do pensamento mágico é a lei da acumulação e da complicação crescente, o negro deverá procurar elementos por toda a parte".

Como um exemplo bastante plástico da lei da acumulação, - aqui associando-a fortemente com a lei da magia e a sua tendência ao acumulativo -, Bastide (1983) cita os balangandãs das baianas típicas: "O balangandã multiplica num mesmo suporte figas arcaicas, romanas, trazidas de Portugal, estrelas de Salomão, de origem judaica, chifres contra mau-olhado, corações, pombas, de origem cristã, chaves, tambores africanos etc.”. No mesmo parágrafo, esse sociólogo parte do mesmo princípio para dissociar magia de feitiçaria, dizendo: “Aliás, o que facilita o sincretismo é a homogeneidade de símbolos mágicos mais ou menos os mesmos em toda a face do globo e em todas as épocas (magia do pó, magia da abertura etc.) e a monotonia dos ingredientes da feitiçaria”.

Para os nossos limitados objetivos, vamos tentar reduzir esse tópico do sincretismo religioso a dois aspectos destacados por Roger Bastide (1983, p.159-191): a penetração do candomblé no ritual católico e a penetração do catolicismo no candomblé. Em Salvador, pelo menos, tem-se uma viva demonstração do primeiro aspecto durante as festas inicialmente católicas em louvor a Nosso Senhor do Bonfim, Nossa Senhora da Conceição da Praia, Senhora Santana, Santo Antônio da Barra, Pilar, Nossa Senhora das Candeias e São Bartolomeu. Já a penetração do catolicismo no candomblé apresenta-se com mais complexidade do que o primeiro aspecto mencionado brevemente no parágrafo acima. No entanto, a despeito disso, Bastide fornece-nos alguns exemplos plásticos: o altar do barracão, as imagens de santos nas paredes dos barracões e alguns cânticos. 
Sobre o primeiro item, diz o sociólogo francês que não parece haver função alguma para aquele móvel, "um objeto anexado, justaposto como um corpo morto".

Por outro lado, é bom se relembrar que o fator principal do embate entre Zé-do-burro e o Padre deveu-se ao fato do primeiro ter feito a promessa a Santa Bárbara em um altar de um terreiro. Roger Bastide detectou ainda nos candomblés que visitou no Nordeste no final dos anos 50 a presença de imagens de santos nos alojamentos dos fiéis e uma lamparina acesa à noite em sua homenagem. Por fim, baseando-se no livro Candomblé da Bahia (1942), de Donald Pierson, Bastide (1983, p.176) registra vários cânticos em português (alguns incluindo versificações da Bíblia) nos terreiros bantos ou dos candomblés de caboclos.

Se o herói clássico, na tragédia ática, bate-se, principalmente, contra a "força do destino", a personagem-título da peça em questão em questão enfrenta forças sociais, personificadas, na imprensa, na Polícia, seja através de um prosaico guarda de trânsito ou do Delegado, e na igreja católica, através do Padre e do Monsenhor.

Aparentemente, em termos de uma teoria da tragédia, a presença do satírico cordelista na peça $O$ pagador de promessas poderia servir como mais um elemento de afastamento do seu texto da estrutura da tragédia ática, exercício de aproximação que se pretende aqui desde o seu início. No entanto, essa personagem não se encontra tão distante da história da tragédia como se poderia imaginar por vários motivos. Na mitologia grega, sátiros (sátyroi), acompanhantes de Diôniso, eram considerados como os espíritos das florestas e das colinas e eram associados especialmente à fertilidade, à lubricidade, às orgias. Segundo Harvey (1987, p.453-454), eles eram representados como figuras grotescas. Eram caracterizados como sátiros os componentes do coro dos dramas satíricos. Assim como as tragédias estavam associadas às cerimônias religiosos, as sátiras também nela se faziam presentes com o fito de intervirem no impedimento de calamidades. Inicialmente, as sátiras eram as denominações de uma literatura de miscelânea, onde variavam os temas bem como as formas narrativas: diálogo, fábula, historieta, preceitos e versos de metros variados.

Ao passo em que a personagem do cordelista remete aos cultos dionisíacos, ela serve também como mais um contraponto, pela baixeza de caráter, à bondade, às virtudes de Zé-do-burro. Desde as suas primeiras aparições, Dedé Cospe-Rima torna claro que é capaz de impedir a confecção de um folheto seu, desancando alguém, se a futura vítima se prontificar a suborná-lo. Além disso, a sua presença aponta para outras direções. De uma certa forma, a presença de um 
cordelista na capital, cuja área de atuação historicamente se dava em mercados e feiras-livres do interior rural, indica uma dinâmica socioeconômica. Essa dinâmica se dá por força dos processos migratórios, pois espera-se que ele, o cordelista, esteja em áreas em que o acesso à leitura seja restrito e que a simples leitura de seu cordel seja o jornal dos que não sabem ou não podem ler. Curiosamente, a caracterização do poeta Dedé Cospe-Rima, personagem que mais de perto poderia espelhar, em $O$ pagador de promessas, a profissão de literato, é marcadamente acentuada pela baixeza de caráter. A isto se acresce o fato de ele buscar sobreviver não pela remuneração daquilo que produz como artista autônomo, mas pelo que lhe rende não produzir, chantageando as pessoas que cometem atos de infração.

Enquanto o poeta-sátiro tem revelado desde o início o seu caráter venal, o repórter vai aos poucos dizendo a que veio. Inicialmente, é o jornalista entusiasmado que descobre, na rotina beata da celebração do dia de Santa Bárbara, um fait divers típico: alguém que já cumpriu uma dura jornada e que não desiste de entrar numa igreja católica para pagar uma promessa feita em um terreiro de candomblé. Os diálogos de Zé-do-burro com esse repórter se transformarão adiante em um dos vários motivos para a presença da Polícia no local: um simplório produtor rural é difundido pelo jornal como um "subversivo". Constatado o conflito insolúvel - a intransigência do Padre em permitir a entrada de Zé com sua cruz naquele templo católico -, o repórter percebe que pode criar um mito de massa, fazer com que o jornal em que trabalha venda mais exemplares e que Zé venha a apoiar um determinado político.

\section{Mídia e entretenimento}

O que se tem, com a caracterização do Repórter, entre outras coisas, é uma caricatura de uma exacerbação de uma das funções dos meios de comunicação de massa: o entretenimento. Como sintetizou Lasswell (1948, p.106-107), em "A estrutura e a função da comunicação na sociedade", pode-se distinguir claramente mais três funções, que correspondem a certas especializações, a saber: a vigilância sobre o meio, a correlação das partes da sociedade em resposta ao meio e a transmissão da herança social de uma geração para a outra. No caso do repórter da peça, tem-se tão somente, além da função de entretenimento - que o fait divers proporciona - a função de vigilância, assim conceituada por esse autor americano: "Em algumas sociedades, certos membros desempenham papéis especializados de vigilância sobre o meio. Agem como ' sentinelas', ficando à parte do grupo, como observadores, e manifestando-se sempre que ocorre alguma mudança alarmante nos 
arredores".

Personagens fundamentais para que a promessa de Zé-do-burro seja cumprida mesmo com ele morto, os capoeiristas, representados nas falas de Mestre Coca, entram em cena quando já está definida a interdição do acesso de Zé com a cruz à igreja por decisão do Padre. A participação deles só começa a tomar corpo no canto puxado pelo Mestre do Coro, denominação curiosa pois remete ao "cabeça do coro", o corifeu da tragédia ática. Na peça em análise, é claro, esse coro, formado pelos próprios tocadores da roda de capoeira, não tem as funções dramáticas que a notabilizaram na Grécia clássica. Tem-se rapidamente os capoeiristas gingando, o que é uma pena em termos de informação, e uma informação com relação ao sincretismo religioso. Normalmente, o jogo de capoeira tem essa espécie de "prólogo": os capoeiristas se aproximam do espaço da luta - a arena - e se agacham em frente aos instrumentistas, chamados de "orquestra". A partir desse momento, rezam as normas, eles devem ficar calados ao tempo em que o coro vai cantando, em geral, versos referentes à capoeira, malandragem, armas e fé. Após essa cantoria acima, tem início a luta-dança. Esse canto inicial é chamado de "preceito", mas se tem popularmente como uma reza ou a espera do "santo". O segundo momento de destaque desses capoeiristas é justamente na consecução da promessa de Zé-do-burro. Ao tempo que o camponês começa, morto, a trajetória da glória, os capoeiristas, como signos da cultura afro-brasileira, trazem, com eles, o sincretismo para dentro de um espaço que não quer reconhecer a sua irreversibilidade: a igreja católica.

Ao passo em que, até esse ponto, se aposta numa eventual pertinência em associar traços da tragédia ática com uma peça brasileira do início dos anos 1960, há obviamente que se reconhecer as divergências mais importantes, a saber: a) a caracterização do protagonista; b) a divisão em partes; e c) as questões religiosas.

\section{Caracterização do protagonista}

Ao longo do tempo, foi-se consolidando uma norma, que se tem como aristotélica, que a tragédia clássica somente poderia ser protagonizada por reis, nobres e aristocratas. No entanto, consultando-se A poética (Aristóteles,1998, p.45), nota-se registro diverso: "Visto ser a tragédia representação de seres melhores do que nós...”. No século XIX, a tragédia burguesa (como era inevitável pelo adjetivo) põe por terra a norma que as personagens deveriam ser reis, homens de Estado ou heróis, o que, como já dissemos, Aristóteles jamais defendeu. Quando a essas classes 
sociais ele se referiu, foi ao comentar as epopeias de Homero. Considerando o sofrimento por qual passa Zé-do-burro, por seu final apocalíptico e em especial pela caracterização de seu personagem, nitidamente marcado pela ingenuidade e pela obstinação em cumprir sua promessa, podemos comparar nosso herói às figuras trágicas nas considerações do texto aristotélico.

Ainda com relação a esse tópico personagem-classe social, para Albin Lesky (2003, p.33), em lugar da alta categoria social dos heróis trágicos, passou-se a aceitar como requisito a "considerável altura da queda". Ou seja: "O que temos de sentir como trágico deve significar a queda de um mundo ilusório de segurança e felicidade para o abismo da desgraça ineludível”.

Antes de chegar `a praça em frente à igreja de Santa Bárbara, em Salvador, Zé-do-burro era um pequeno proprietário, frequentava um terreiro de candomblé, mas isso não o indispunha com o vigário local. O seu casamento parecia tranquilo, a salvação do burro Nicolau era uma prova de que ele andava de bem com o divino - no caso, representado por Santa Bárbara - e, na sua procissão em direção à Capital, ninguém via qualquer tentativa de heresia em sua simplória imitação de Cristo, muito pelo contrário pelo que se depreende dessas falas de Rosa com Bonitão: "Pelo caminho, tinha uma porção de gente querendo que ele fizesse milagre. E não duvide. Ele é capaz de acabar fazendo. Se não fosse a hora, garanto que tinha uma romaria aqui, atrás dele”.

\section{A divisão em partes}

A tragédia grega clássica tinha, em geral, cinco partes: prólogo, episódio, êxodo e canto coral. Na peça em pauta, não há nenhuma dessas seções distintas. Com relação à última das seções mencionadas, há acreditamos que vale a pena ser mencionada uma curiosidade. Na tragédia ática, Lesky (2003, p.85;101), chama-nos a atenção para o fato de que o canto coral (veiculado através de 50 cantores) estava representando o que era da "ordem dos sentimentos", enquanto as falas do ator servem ao desenvolvimento e ao exame do que é temático". Na peça em pauta, tem-se um Mestre do Coro, mas o coro aqui, composto por músicos e praticantes de capoeira, não tem a função que lhe é reservada na tragédia ática clássica, principalmente aquela de comentar as ações dos heróis, valorando-as positiva ou negativamente. Cabe registrar que o coro nem sempre teve o mesmo papel. Ésquilo, autor que introduziu o prólogo explicativo, esclarecendo o mito básico da trama, por exemplo, reduziu as partes do coro, assegurando assim prioridade às falas. 


\section{As questões religiosas}

Outro item importante nas divergências entre o contexto da tragédia grega clássica e aquele da peça brasileira diz respeito às questões de natureza religiosa. A vinculação da apresentação das tragédias na Grécia clássica às celebrações de Diôniso pode levar a uma associação rápida entre o ato teatral e o ato religioso respectivo. No entanto, Lesky (2003, p.77-78) chama-nos a atenção sobre dois aspectos relacionados ao religioso e à tragédia ática:

A época das festas, o lugar da representação, a vestimenta dos atores, tudo aponta para o deus, mas o conteúdo das tragédias, na medida em que podemos dizer algo a respeito, indica uma direção totalmente diferente [...]. Em Diôniso, encontramos possivelmente uma das forças vivas que impulsionaram o desenvolvimento do drama trágico como obra de arte, mas, quanto ao conteúdo, a tragédia foi configurada por outro campo da cultura grega, pelo mito dos heróis.

A aparente contradição entre a tragédia como parte do culto dionisíaco e seu conteúdo não-dionisíaco foi observada muito cedo pelos antigos e deu margem a uma expressão proverbial: "Isto não tem nada a ver com Dioniso".

Muito resumidamente, na mitologia greco-romana, Diônisos, é filho de Zeus e de Semele e é representado em suas conquistas por um séquito, composto por devotos, sátiros, silenos, mênades e bassáridas, dançando à sua volta, esquartejando animais, embriagados e possessos. É o deus do vinho, o qual alivia as preocupações e inspira os artistas para a música e para a poesia. Daí, a sua estreita conexão com o ditirambo, a tragédia e a comédia. Os mitólogos atribuem a esse deus olímpico a entrada na religião grega da época clássica dos elementos de êxtase e misticismo (Harvey, 1987, p.168). Mas é imensa a relação dos deuses greco-romanos da citada época. Há os deuses olímpicos, deuses subolímpicos (a Aurora, o Sol, a Lua, a Tempestade, entre outros), os deuses da pátria, da família, da vida humana, o mundo infernal e as divindades alegóricas e as divindades do mar e das águas, das montanhas, dos bosques, as divindades campestres, divindades do campo e da cidade. Os deuses do Olimpo - a elite da elite - eram Júpiter (Zeus), Juno (Hera), Minerva (Palas-Atena), Apolo (Febo), Diana (Ártemis), Ceres (Demeter), Mercúrio (Hermes), Marte (Ares), Vênus (Afrodite), Baco (Dionísio), Cúpido, Íris, Ganymedes, as Graças ou Carites, as Musas e as Parcas, entre outros. Entre todos esses, sobressai-se Zeus. 
Pelos atributos sintetizados acima é que muitos historiadores da Grécia clássica tendem a rejeitar que àquele período histórico se aplique o adjetivo politeísta, uma vez que o culto a Zeus, na forma como era feito e os poderes que dispunha, o colocavam como o Deus, e não apenas mais um deus. Argumento semelhante se tem em especialistas na cultura afro-brasileira, que afirmam ser o candomblé praticado no Brasil litoral uma manifestação de religiosidade monoteísta, argumento que poderia, no caso de O pagador de promessas, ser levantado em defesa de Zé, mas isto não pode se dar uma vez que o Padre rejeita o candomblé, principalmente por ser uma prática fetichista. Vale a pena frisar que, se, na Grécia clássica, o politeísmo, como se entende hoje, fosse uma prática livre, Sócrates não teria como peças de sua condenação à morte dois crimes que afrontavam a ordem da cidade-Estado à época: não reconhecer os deuses do Estado e introduzir novas divindades. Uma síntese desse complexo entrelinhamento religião-mitologia-Estado na Grécia clássica nos é fornecida por Junito Brandão (1985, p.11):

$\mathrm{Na}$ Grécia [clássica], todas as correntes religiosas confluem para uma bacia comum: sede de conhecimento contemplativo (gnôsis), purificação da vontade para receber o divino (kátharsis) e libertação desta vida geradora, que se estiola em nascimentos e mortes para uma vida de imortalidade (athanasía).

Mas essa mesma sede nostálgica de imortalidade, preconizada pelos mitos naturalistas de divindades da vegetação, que morre e ressuscitam divindades (Dioniso, sobretudo), essencialmente populares, chocava-se violentamente com a religião oficial e aristocrática da pólis, cujos deuses olímpicos estavam sempre atentos para esmagar qualquer desmedida de pobres mortais, que aspirassem à imortalidade.

Os deuses olímpicos sentiam-se ameaçados e o Estado também, uma vez que o homo dionysiacus, integrado em Dioniso, através do êxtase e do entusiasmo, se libera de certos condicionamentos e de interditos de ordem ética, política e social.

\section{O panteão greco-romano}

À semelhança do que se tem hoje nos diversos cultos afro-brasileiros, que não se restringem, como se sabe ao candomblé litorâneo, o panteão grego-romano comportava também divindades relacionadas à natureza, como as divindades do mar e das águas (o Oceano, as Sereias, os Rios, as Fontes e as Águas Estagnadas), das montanhas, dos bosques e as divindades campestres (a exemplo de as Montanhas, os Bosques, Narciso, a Ninfa Eco, Pã, Príapo, Dafnis, Egipãs, Sátiros e Silenos, esses dois últimos da entourage de Diôniso). Entre dezenas de outras divindades, o panteão grecoromano possuía ainda as divindades alegóricas, estas popularizadas a partir do teatro medieval em 
autos pararreligiosos. E são muitas as divindades: Amizade, Boa Fé, Má Fé ou Fraude, Calúnia, Concórdia, Discórdia, Esperança, Fama (mensageira de Júpiter) Fome, Gratidão, Inveja, Justiça, Lara, Mnemósine ou Memória, Muta ou Tácita, Paz, Persuasão Piedade, Pluto, Pobreza, Prudência, Sabedoria, Saúde, Verdade (mãe da Justiça e da Virtude), Velhice, Virtude, Vitória e Volúpia, entre outras.

Como se sabe, os orixás são divindades cultuadas nas religiões afro-brasileiras e, originariamente, eles personificam forças e fenômenos da natureza, servindo como intermediários entre devotos e Olorum, a suprema divindade de alguns povos africanos. Os seus seguidores acreditam que eles moram nas costas da África, e os cânticos e toques de tambores seriam meios de atrai-los. Os orixás mais cultuados em terras brasileiras são os seguintes: Oxalá ou Obatalá, Xangô (o trovão), Ogum (a guerra), Oxum (as águas dos rios e lagoas), Iemanjá (a água do mar), Iansã (a tempestade e o vento), Oxóssi (a caça), Omolu (a peste), Oxumaré (o arco-íris) e Exu (intermediário entre o homem e os outros orixás).

Acreditamos não ser necessária muita intelecção para se associar algumas das divindades do panteão "politeísta" greco-romano com o panteão "politeísta" dos cultos afro-brasileiros, principalmente o candomblé da Bahia, a saber: Zeus / Oxalá ou Obatalá; Ártemis / Oxóssi; Áilos/ Iansã; O Oceano ou Tetis / Iemanjá; os Rios e Águas Estagnadas / Oxum; e Ares ou Marte / Ogum.

Um outro ponto de contato entre universos tão separados no tempo e no espaço diz respeito aos que se denominam de práticas animistas ou fetichistas nos cultos afro-brasileiros e na cultura da Grécia clássica. Nessa última, a associação se dá, para os nossos propósitos investigativos - a aposta na atualização da tragédia ática no roteiro e diálogos de O pagador de promessas - em toda a lenda que cerca a etimologia da palavra tragédia, a saber: 'tragédia' (tragoidia) parece derivar de tragoidoi, significando provavelmente um coro cujos componentes caracterizavam-se para se assemelhar a bodes (trágoi), ou dançavam por um bode como prêmio ou em volta de um bode sacrificado" (Harvey 1987, p.498). Em alguns rituais dos cultos afro-brasileiros, os filhos de santo também sacrificam animais considerados sagrados e oferecem aos orixás seus alimentos preferidos. São essas práticas que são assacadas pelo Padre em seu arrazoado para impedir em outros motivos a entrada de Zé-do-burro com uma (sua) cruz na igreja de Santa Bárbara, como se tem nesse debate:

Padre: (...) além disso, Santa Bárbara, se tivesse de lhe conceder uma graça, não iria faze-lo num terreiro de candomblé! 
Zé: É que, na capela do meu povoado, não tem uma imagem de Santa Bárbara. Mas, no candomblé, tem uma imagem de Iansã, que é Santa Bárbara.

Padre (explodindo): Não é Santa Bárbara! Santa Bárbara é uma santa católica! $\mathrm{O}$ senhor foi a um ritual fetichista. Invocou uma falsa divindade e foi a ela que prometeu esse sacrifício! (Ato I, $\mathbf{2}^{\mathbf{0}}$ quadro).

Se, na tragédia ática, o vínculo tragédia-religião era apenas aparente, o mesmo não podemos dizer do drama $O$ pagador de promessas, que se desenrola em meio a duas celebrações: as missas em louvor à Santa Bárbara e as comemorações em louvor à Iansã. Nele, talvez haja um ou outro elemento a sinalizar uma alegoria de uma outra paixão, alegorização, denunciada veementemente pelo Padre:

- [...] Você acaba de repetir a Via Crucis, sofrendo o martírio de Jesus. Você que, presunçosamente, pretende imitar o Filho de Deus...

- Padre, eu não quis imitar Jesus...

- Mentira! Eu gravei suas palavras! Você mesmo disse que prometeu carregar uma cruz tão pesada quanto a de Cristo.

- Sim, mas isso...

- Isso prova que você está sendo submetido a uma tentação ainda maior.

- Qual, Padre?

- A de igualar-se ao Filho de Deus.

-Não, Padre.

- Por que então repete a Divina Paixão? Para salvar a humanidade? Não, para salvar um burro.

Ao criticar o que seria uma pretensão de Zé-do-burro - imitar a Paixão de Cristo, com os eventuais sucedâneos de fama e glória -, o posicionamento do Padre nos sugere trazer à cena mais um princípio do cristianismo frente ao que o prelado entende como profano. Para isso, apropriamonos, citando, uma exposição sobre a glória, como uma das paixões, de Renato Ribeiro (1987, p.107108) ao falar da paixão chamada glória:

Glória, honra, fama e reputação apontam o renome que tenho, a imagem que os outros vêm em mim. A imagem, pública, assim se opõe à intenção: quando os outros me valorizam ou depreciam pelo que, de mim, é visível não importa o que eu esteja sentindo no mais íntimo. O universo das intenções, a consciência, não pode ser devassado pelo Outro. Desta forma, a honra, a reputação, a fama se afastam do campo propriamente moral ou ético, no qual conta, justamente, a intenção que me move a agir. Um ato pode ser admirado, pode dar relevo social a uma pessoa e, no entanto, dever-se a motivos vis ou o inverso. A religião cristã, em especial, preocupada com a salvação do indivíduo, destaca as intenções, em detrimento do lado público de meus atos. 
Glória, honra, fama, reputação. Esses termos também são importantes no diálogo que o Repórter travará com Zé-do-burro depois de configurado o impasse dele com o Padre. No entanto, há, por parte do jornalista, todo um interesse, a que se associa, entre outras coisas, mais uma vez, a penetração nada religiosa do lucro com os anúncios que o seu jornal teria com as reportagens exclusivas dele com Zé-do-burro, como se tem nesses diálogos com Zé em várias oportunidades:

Repórter: [...]) escute aqui, será que essa história da promessa não é um golpe para impressionar o eleitorado?

Zé-do-burro: Golpe?

-E de mestre! Avalio a agitação que o senhor fez com isso. Pelas estradas, o caminho até aqui, deve ter-se juntado uma verdadeira multidão para vê-lo passar.

- É, tinha...

- Muito moleque também!

- E imaginem a volta! A chegada à sua cidade, em carro aberto, banda de música, foguetes!

- O senhor está maluco? Não vai haver nada disso.

- Vai. Vai porque o meu jornal vai promover. Só faço questão de uma coisa: que o senhor nos dê a exclusividade. Que não conceda entrevistas a mais ninguém. É claro que o senhor terá uma recompensa (Faz com o indicador e o polegar um gesto característico) e também publicidade. Primeira página, com fotografias, o senhor e sua senhora... mandaremos fotografar também o burro - em poucas horas, o senhor será um herói nacional.

- Moço, acho que o senhor não me entendeu... ninguém ainda me entendeu...

- O diabo foi o senhor ter escolhido um dia como o de hoje. Sábado. Amanhã, é domingo, o jornal não sai. Só Segunda-feira. E o nosso Departamento de Promoções precisaria preparar a coisa... Podemos dar o furo na edição de hoje [vespertina], mas o barulho mesmo só Segunda-feira. (Ato II, $1^{\circ}$ quadro).

- Eh, que é isso? Já estão pensando em ir embora?

- Vou embora, quando quiser, não tenho que dar conta disso a ninguém.

- Vocês [Rosa está ao lado de Zé] não estão falando sério, não? Sim, porque eu espero que vocês cumpram o que prometeram. Meu jornal está cumprindo, Já tomei todas as providências para que sua estada aqui até Segunda-feira seja a mais agradável possível (...) Fomos aos nossos clientes, e eles se dispuseram prontamente a colaborar conosco

\section{A divergência principal: a construção da morte}

A maior das divergências entre a estrutura da tragédia ática e a do roteiro e diálogos de $O$ pagador de promessas, em nosso entendimento, dá-se no modo como a cena da morte de Zé-doBurro, é construída, levando o seu drama para perto do seu fim. Na tragédia clássica, que não 
deveria se encerrar necessariamente com a morte do protagonista (vide Édipo Rei, de Sófocles, e Medéia, de Eurípedes, como exemplos), a punição do protagonista-infrator dava-se como resultado de uma sanção, pela qual eram responsáveis algumas dessas instâncias: os deuses, o Estado (no caso de Antígona), um sacerdote, o Conselho de Anciãos, um tribunal ou uma autoridade outra qualquer, seja governamental, religiosa ou comunitária. Ou seja, havia uma clara ligação entre a penalidade para um infrator (no caso de Édipo, ele seu autopune) e a origem da sua determinação. No caso da peça brasileira, a morte de Zé-do-burro surge como fruto de um acidente, acidente este que, entre outras coisas, livra convenientemente as esferas de autoridade com quem ele se defrontou (Guarda, Padre, Monsenhor e Delegado) de uma eventual responsabilidade. Tomemos a descrição do citado acidente como assinala a marcação dessa peça:

Zé-do-burro, de faca em punho, recua em direção à igreja. Sobe um ou dois degraus, de costas. O Padre vem por trás e dá uma pancada em seu braço, fazendo com que a faca vá cair no meio da praça. Zé-do-burro corre e abaixa-se para apanhá-la. Os policiais aproveitam e caem sobre ele, para subjugá-lo. E os capoeiras caem sobre os policiais para defendê-lo. Zé-do-Burro desapareceu na onda humana. Ouve-se um tiro. A multidão se dispersa como num estouro de boiada. Fica apenas Zé-do-Burro no meio da praça, com as mãos sobre o ventre. Ele dá ainda um passo em direção à igreja e cai morto.

Em texto escrito logo após a estreia da peça de Dias Gomes em São Paulo, o crítico Sábato Magaldi (1960, p.3) já chamava a atenção, com outros propósitos, ou seja, do ponto de vista moral, para esse tipo de desfecho em que todas as personagens são culpadas pela morte do protagonista, como se toda a cidade do Salvador tivesse participação no crime, na verdade, um acidente: "Mesmo que a mulher e os sacerdotes sejam responsáveis num grau mais elevado, os figurantes anônimos, atraídos pela simples curiosidade, também contribuem para o desenlace “.

Tendemos a acreditar que o modo como se dá a morte do protagonista da peça em discussão tende a acentuar mais uma divergência da peça do escritor baiano Dias Gomes, com os elementos da tragédia clássica, como queria Aristóteles em suas anotações de aula. Essa divergência estaria na ausência, na peça em análise, em nosso entendimento, dos elementos para o estabelecimento do temor e da compaixão na plateia, motivados por um mesmo fato. Se a compaixão pode ser instalada devido ao fato de que temos ali, no palco, uma pessoa como nós, um pouco mais virtuosa, quem sabe - Aristóteles, como se sabe, frisa que o protagonista não pode ser muito ruim nem muito bom porque aí as gentes não se identificariam com ele -, temos dúvida com relação ao temor. 
Para que o temor se instalasse seria necessário, em nossa argumentação, que o protagonista tivesse sido autopunido ou punido diretamente pelo antagonista, sejam os deuses, contrariados, um sacerdote ou o Estado. Dificilmente, podemos acreditar que o público possa sentir temor de ser vitimado por um acidente. Ou seja, teria que ficar bem clara origem da punição, bem clara quer dizer claramente identificada, pois aí, então, personificado esse antagonista, haveria o que se temer, pois haveria a quem ou ao que se temer.

Ocorrida a morte de Zé-do-burro, há, então, a peripécia - "uma viravolta das ações em sentido contrário" (Aristóteles,1998, p30;39) - reviravolta, que não se teve durante todo o tempo. E aqui, mais uma vez, manifesta-se, na escolha das personagens que vão configurar essa peripécia segundo Aristóteles, momento em que se obtém a "emoção trágica" e os "sentimentos de humanidade", os capoeiristas, a opção política do teatrólogo Dias Gomes. Após uma breve e tensa troca de palavras entre Rosa, Padre e Delegado, Mestre Coca assume a cena:

O Padre abaixa a cabeça e volta ao alto da escada. Bonitão surge na ladeira. Mestre Coca consulta os companheiros com um olhar. Todos compreendem a sua intenção e respondem afirmativamente com a cabeça. Mestre Coca inclinase diante de Zé-do-Burro, segura-o pelos braços, os outros capoeiristas se aproximam também e ajudam a carregar o corpo. Colocam-no sobre a cruz, de costas, com os braços estendidos, como um crucificado. Carregam-no assim, como numa padiola e avançam para a igreja. (...) Intimidados, Padre e Sacristão recuam, a Beata foge, e os capoeiras entram na igreja com a cruz, sobre ela o corpo de Zé-do-Burro. O Galego, Dedé e Rosa fecham o cortejo.

\section{O papel da ekédi}

A personagem Minha Tia, por sinal única figura do candomblé em cena, além disso, desempenha várias funções e é, de certa forma, um símbolo de vários aspectos da cultura afrobrasileira. Logo na sua entrada, ela é caracterizada como uma quituteira, fazendo o seu pregão: “Zé e sua cruz continuam no meio da praça. Ouve-se um pregão: 'Beiju...olha o beiju!' Logo após, surge no alto da ladeira uma preta em trajes típicos com um tabuleiro na cabeça" (Ato II, $\mathbf{1}^{\circ}$ quadro). Por sinal, o pregão está mais ligado às origens pretéritas de uma indústria cultural no Brasil como nos informa o historiador musical José R. Tinhorão (1976, p.49): “O pregão pode ser apontado como uma das formas mais antigas de publicidade tipo jingle, considerada a origem mesma dessa palavra inglesa, que inclui, entre seus significados, o da 'repetição de palavras de som igual ou semelhante, especialmente para chamar a atenção”. Já o folclorista Luís da Câmara Cascudo (1984 p.631) nos 
informa que os pregões de rua são "vozes ou pequenas melodias com que os vendedores ambulantes anunciam a sua mercadoria. São conhecidos no mundo inteiro e em todos os tempos".

Ao surgir em cena mercando, Minha Tia torna visível e ilustra também uma relação forte que há entre a devoção a Santa Bárbara e as atividades relativas a certo tipo de comércio varejista, relativo à venda de alimentos - temperos, fatos de boi, peixes, mingaus, cuscuz, cocadas -, bem como relativo às ganhadeiras em geral, estas últimas figuras fortes ainda no escravismo. Pesquisadores de cultos religiosos na África, nos anos 1940, assinalavam que as vendedoras, como Minha Tia, eram responsáveis de certa forma pelos elos de ligação entre um mundo de ganho, de comércio, de lucro, enfim, e um mundo relativo aos costumes da tradição religiosa.

Em sua segunda entrada em cena, Minha Tia, como parte do quadro de pessoas que oferecem uma alternativa para Zé a qual se transforma em mais um "prova", coloca uma saída para o impasse que já havia sido instalado, informando da sua posição no terreiro de Menininha do Gantois - ekédi - e que, lá, ele poderia cumprir a sua promessa. Mas a alternativa sincrética, que, para Minha Tia, não é um problema esbarra com a ideia-fixa de Zé: "Não foi num terreiro que eu disse que ia levar a cruz, foi numa igreja. Numa igreja de Santa Bárbara". Mesmo com essa fala, mais adiante, Minha Tia, ao se esbarrar com Rosa, manda um estímulo para que o marido dela permaneça com seu propósito: "Diga a ele que não desanime, Iansã tem força!"

É ainda Minha Tia quem traz para a cena um dos símbolos da festa profana, que se realiza perto da igreja: o caruru de Santa Bárbara. Aqui, a comida não é mais servida gratuitamente como se tem dentro do mercado homônimo, na Baixa dos Sapateiros, mas sim vendido, mudança que ela acentua ser devido a questões mais de conjuntura inflacionária do que de mudança de costumes: "Caruru de Santa Bárbara. Antigamente, a gente fazia isso e era de graça. Hoje, com a vida do jeito que está, a gente tem mesmo é que cobrar". Reginaldo Prandi (2005, p.103) nos oferece uma explicação socioeconômica para essa associação Iansã- comércio, informando-nos que a vida econômica da maioria dos povos africanos do território iorubá foi feita através da agricultura, da caça, da pesca e do artesanato, mas que havia uma "intensa e importante atividade comercial", que era centralizada nos mercados urbanos, "para onde acorria a produção das diferentes aldeias e cidades". Esse antropólogo chama-nos a atenção para o fato de que "[...] podemos ver nessa sociedade em formação um deslocamento dos orixás: do plano dos fenômenos da natureza para o plano da divisão social do trabalho, assumindo os orixás a característica de guardião de atividades essenciais para a vida em sociedade". 
Na primeira vez em que Minha Tia cruza com Zé do Burro, ela lhe dá uma série de informações, que nos chamam a atenção pelo fato de dar a entender que Zé não sabe muita coisa dos cultos afro-brasileiros, o que é curioso pois ele, em discussão com o Padre, havia afirmado a identidade entre Iansã e Santa Bárbara. As falas e atos acima brevemente resumidos são a sinalização mais evidente, em todo o texto, do partido que o dramaturgo Dias Gomes está tomando diante da presença do sincretismo religioso na cultura brasileira desde a chegada dos primeiros navios negreiros e de sua intolerância por uma certa igreja católica. Ao mesmo tempo, essas marcações acentuam a força mediúnica da quituteira, que, assim, fica como se fosse uma espécie de mensageira do divino, capaz de, em poucas palavras, unir manifestações da natureza às epifanias.

A fala integral de Minha Tia é essa:

- Não desanime, moço. Hoje, é dia de Iansã, mulher de Xangô, Orixás dos raios e das tempestades. Mais logo, nos terreiros, ela está descendo no corpo dos seus cavalos. Vai falar com ela, moço, vai pedir a proteção de Iansã, que tudo quanto é porta há de se abrir (Ouvem-se trovões mais fortes que da vez anterior) Óia! (Aponta para o céu) Iansã está falando! (Abaixa-se, toca o chão com a ponta dos dedos, depois, a testa e saúde Iansã) Êparrei, minha mãe!

As marcações do Autor acima acentuam a força mediúnica da quituteira, que, assim, fica como se fosse uma espécie de mensageira do divino, capaz de, em poucas palavras, unir manifestações da natureza às epifanias. $\mathrm{Na}$ defesa do que se argumenta aqui, gostaríamos de destacar que é uma fala de Minha Tia que encerra a peça - Êparrei, minha mãe! -, como se essa frase estivesse autenticando por sua fé sincrética a atuação de Iansã-Santa Bárbara fazendo com que, finalmente, Zé-do-burro entre na igreja com a sua cruz, mesmo que morto e estirado sobre ela, carregados por capoeiristas, simbolizando, através do mártir, uma vitória dos cultos afro-brasileiros.

As breves observações acima a propósito da fundamental personagem que é Minha Tia acabam por nos proporcionar também uma outra entrada de análise para algo que é muito forte na peça, o comércio, mas que, eventualmente, possa ficar em segundo plano em cena diante dos conflitos Zé-do-burro versus Padre. E as representações do mundo mercantil não se esgotam apenas, como poderia parecer à primeira vista, nas atividades de Minha Tia e Galego, por exemplo. Há muito mais. E esse algo mais vai apontar na direção de uma leitura da peça como uma denúncia da penetração da motivação do lucro em quase todas as atividades em cena. As primeiras falas explícitas na direção do que se afirma acima surgem em um lugar onde talvez elas pudessem ser menos esperadas: a relação erótica (mas sem afeto, pelo menos de uma parte) entre Bonitão e Marli. 
Como se tem nesses diálogos:

Bonitão (para Marli): Espere. Não adianta andar depressa...

Marli: É melhor discutirmos isso em casa.

- Não, vamos resolver aqui mesmo. Não tenho nada que discutir com você...

- Estúpido.

- Ande, vamos deixar de mas-mas. Passe prá cá o dinheiro.

- Não podia esperar até chegar em casa?

- Só deu isto?

A motivação para o lucro também persegue o poeta Dedé, que alardeia ganhar mais quando não publica, chantageando e extorquindo as eventuais personagens-chave de seus cordéis. Essa postura condenável o credencia, quem sabe, a ver na atividade pastoral do Padre mais um "negócio". Curiosamente, até o próprio Zé-do-burro, ao dialogar com Rosa a propósito de valores que ele tem como positivos, como parâmetros para prosseguir no cumprimento de sua promessa, assaca valores de comerciantes ou normas mercantis, a saber:

Zé: Se a gente embrulha o santo, perde o crédito. De outra vez, o santo olha, consulta lá os seus assentamentos e diz: 'Ah, você é Zé-do-burro, aquele que já me passou a perna! E, agora, vem me fazer nova promessa. Pois, vá fazer promessa pro diabo que o carregue, seu caloteiro de uma figa! E tem mais: santo é como gringo, passou calote num, todos os outros ficam sabendo. (Ato I , $1^{\circ}$ quadro)

Rosa: Quem é que vai roubar uma cruz, homem de Deus? Pra que serve uma cruz?

- Tem tanta maldade no mundo. Era correr um risco muito grande, depois de Ter quase cumprido a promessa. E você já pensou; se me roubassem a cruz, eu ia Ter que fazer outra e vir de novo com elas nas costas da roça até aqui. Sete léguas.

- Pra quê? Você explicava 'a santa que tinha sido roubado, ela não ia fazer questão.

- É o que você pensa. Quando você vai pagar uma conta no armarinho e perde o dinheiro no caminho, o turco perdoa a dívida? Uma ova! (Ato I, $\mathbf{1}^{\mathbf{0}}$ quadro)

O vocabulário comercial é acionado por Zé até mesmo frente à quem vive longe dele, o Padre, quando este lhe pergunta o que ele vai fazer após cumprir a promessa: Que pretendo? Voltar pra minha roça, em paz com a minha consciência e quite com a santa. A rigor, não nos parece que a peça esteja criticando simplesmente as atividades comerciais ou o mercantilismo, tomando-se como exemplos as falas destacadas acima. Tendemos a pensar que a alta incidência das referências ao comércio serve de certa forma para preparar o espírito do leitor ou espectador para o que nos 
parece também uma mensagem que se vai construindo: associar a penetração das relações de comércio, mediadas pela mercadoria, nas relações pessoais. O diálogo Bonitão-Marli é o maior exemplo (ou o pior do ponto de vista moral) do que dizemos, pois aí se trata de um crime, o lenocínio, mas é justamente em um dos diálogos dessa dupla, que, por uma má estranha visão de mundo de Bonitão, a "mensagem" autoral (corporificada em diálogos que se referem metaforicamente ao fetichismo da mercadoria, ao trabalho alienado, à mais-valia), se dramatiza, por vias transversas, principalmente quando se ilustra, através de uma cena de lenocínio, a propriedade privada, por parte de Bonitão, de um “meio de produção", o corpo da prostituta Marli:

- Escute, Bonitão... você não podia deixar eu ficar ao menos com aquela nota?

- Já lhe disse que não. Não insista.

- Mas eu preciso pagar o quarto!

- O quarto é seu, não é meu.

- Mas o dinheiro é meu. É justo que eu fique ao menos com algum.

- É justo por quê?

- Porque fui eu que trabalhei.

- E, desde quando, trabalhar dá direito a alguma coisa? Quem lhe meteu na cabeça essas ideias? (Olha-a de cima a baixo, com desconfiança). Está virando comunista? (Pano rápido).

\section{Considerações finais}

Esperamos ter demonstrado, principalmente a partir das teorias da tragédia, os pontos em comum e aqueles divergentes entre a estrutura da tragédia grega (ática) clássica e a peça brasileira O pagador de promessas, levando em igual consideração aspectos relativos ao conteúdo propriamente dito (tema e contexto: politeísmo e sincretismos com a penetração do candomblé no catolicismo e vice-versa e a dinâmica do candomblé, principalmente no deslocamento de função dos orixás de ambientes mais próximos à natureza para locais de atividade comercial), bem como aspectos relacionados à forma (carpintaria teatral, caracterização dos protagonistas e de seus antagonistas, a criação do temor e da compaixão, as concepções de "dignidade da queda", a "considerável altura da queda", o "conflito trágico cerrado", a "visão cerradamente trágica' e a "situação trágica".

Nesse ponto do nosso texto, talvez seja a hora de se perguntar: o que tem a ver o drama $O$ pagador de promessas com assuntos relativos à África e à diáspora africana? Entendemos que o princípio de uma resposta pode estar no fato de que, ao longo dessa peça, de maneira sutil, artística, 
faz-se uma longa defesa dos sincretismos religiosos. E como se falar de sincretismos sem se levar em conta, no nosso caso, o brasileiro, as diásporas africanas? O falecido crítico cultural jamaicano Stuart Hall (1996, p.68-75) já havia chamado a atenção de que o hibridismo é uma característica das diásporas, uma vez que as culturas delas resultantes espelham as marcas de sua origem ao mesmo tempo em que refletem aspectos importantes da cultura do "lugar de residência". Ele vai além em sua argumentação, ao defender um paradoxo: a ideia de que uma eventual "unidade" das culturas da diáspora africana é uma das consequências mais visíveis do "desenraizamento da escravidão" e do tráfico e a inserção na "grande lavoura (bem como na economia simbólica") do mundo ocidental", os quais seriam os responsáveis pela "unificação" desses povos, "através de suas diferenças, no mesmo momento em que eles eram privados do acesso direto ao seu passado" (HALL,1996, p.70).

De passagem, talvez valha a pena lembrar que os temas tratados nessa peça de Dias Gomes - sincretismo religioso, intolerância de um segmento da Igreja católica brasileira e reforma agrária talvez tenham sido os motivos principais para que sua adaptação cinematográfica - homônima filmada em 1962 por Anselmo Duarte, tenha sido proibida pelo governo militar brasileiro entre os anos de 1967 e 1972.

\section{Referências bibliográficas}

ARISTÓTELES. Poética. São Paulo: Cultrix, 1998.

BASTIDE, Roger. Estudos afro-brasileiros. São Paulo: Editora Perspectiva, 1983.

BRANDÃO, Junito. Teatro grego. Petrópolis, RJ: Vozes, 1985.

CARNEIRO, Edson. Antologia do negro brasileiro. Rio de Janeiro: Ediouro. $5^{\mathrm{a}} \mathrm{ed}, 1982$.

CASCUDO, Luís C. Dicionário do folclore brasileiro. Belo Horizonte: Itatiaia, 1984.

BORNHEIM, Gerd. O sentido e a máscara. São Paulo: Perspectiva, 1975.

GOMES, Dias. O pagador de promessas. Rio de Janeiro: Ediouro, 28ª ed., 1996.

HALL, Stuart. "Identidade cultural e diáspora". Revista do Patrimônio Histórico e Artístico Nacional, $\mathrm{n}^{\mathrm{o}} 44,1^{\circ}$ semestre, pp.68-75, 1996.

HARVEY, Peter. Dicionário Oxford de literatura clássica. Rio de Janeiro: Jorge Zahar, 1987.

LASSWELL, Harold. “A estrutura e a função da comunicação na sociedade”. In COHN, G. (org.) 1982. Comunicação e Indústria Cultural. São Paulo, TAQ, p.105-16, 1948. 
LESKY, Albin. A tragédia grega. São Paulo: Perspectiva. 2003 [1937]

MAGALDI, Sábato. "O pagador de promessas". O Estado de São Paulo, "Suplemento Literário", 23 de julho de 1960, p.3.

PRANDI, Reginaldo. Segredos guardados. São Paulo: Companhia das Letras, 2005.

RIBEIRO, Renato. “A glória”. In NOVAES, Adauto (org.). 1987. Os sentidos da paixão. São Paulo: Companhia das Letras, p.107-16.

SAID, Edward. Reflexões sobre o exílio. São Paulo: Companhia das Letras, 2003..

Robert Stam; Ella Shoat. Unthinking Eurocentrism. London: Routledge, 1997.

SZONDI, Peter. Ensaio sobre o trágico. Rio de Janeiro: Jorge Zahar. 2004.

TINHORÃO, José R. Música popular - os sons que vêm da rua. São Paulo: Tinhorão, 1972. 